\title{
TROPICAL OCHROPHYTE ALGAE FROM THE EOCENE OF NORTHERN CANADA: A BIOGEOGRAPHIC RESPONSE TO PAST GLOBAL WARMING
}

\author{
PETER A. SIVER ${ }^{*}$ and ALEXANDER P. WOLFE 2 \\ ${ }^{1}$ Connecticut College, Botany Department, New London, Connecticut 06320, USA; ${ }^{2}$ University of Alberta, \\ Department of Earth and Atmospheric Sciences, Edmonton, Alberta T6G 2E3, Canada \\ e-mail:pasiv@conncoll.edu
}

\begin{abstract}
We report on exquisitely preserved specimens of freshwater siliceous algae belonging to the classes Synurophyceae (scaled chrysophytes) and Bacillariophyceae (diatoms) from middle Eocene lake sediments in Northern Canada. When considered in the context of closest extant relatives, these microfossils present unequivocal biogeographic and ecological affinities with warm-water ochrophyte assemblages. We have identified scales that are unambiguously assigned to Mallomonas bangladeshica, a chrysophyte now restricted to tropical lake ecosystems. The diatom genus Actinella is also well represented in these sediments, again with the most comparable extant congeners found in tropical to subtropical localities, particularly in the Southern Hemisphere. We surmise that fundamental biogeographic reorganizations among lacustrine algae took place during Eocene hothouse paleoclimates. In this light, future climate warming should be viewed as a potent vector for similar community shifts, with attendant limnological implications.
\end{abstract}

\section{INTRODUCTION}

The paleoclimatology of the Paleogene has received renewed interest because of possible analogy with anthropogenic climate warming. Indeed, enhanced greenhouse-gas loading appears to be a first-order explanation for anomalous warmth during the Paleogene, particularly at the Paleocene-Eocene boundary (55 Ma), and it persisted for at least $10 \mathrm{myr}$ (Pagani et al., 2005; Zachos et al., 2008). At this time, latitudinal temperature gradients were greatly reduced, and the planetary cryosphere was vastly diminished or absent (Greenwood and Wing, 1995). These conditions are well exemplified by the presence of fossil conifer forests at polar latitudes in the Canadian Arctic (Greenwood and Basinger, 1994).

Paleogene greenhouse climates had fundamental consequences for ecosystems globally. Significant shifts in species diversity, community composition, and biogeographic range have been documented for a wide range of organisms, including fungi (Kalgutkar and McIntyre, 1991), pteridophytes (Brinkhuis et al., 2006), higher plants (Wing et al., 1995; 2005), mammals (Clyde and Gingerich, 1998), marine bivalves (Bice et al., 1996), and foraminifera (Kelly et al., 1988; Pak and Miller, 1992). By comparison, relatively little is known concerning Paleogene limnic organisms in general and siliceous ochrophyte algae in particular, in part because suitable sediments have been understudied. In this communication, we report on freshwater algae with pronounced tropical affinities from a small middle Eocene lake in northern Canada. This confirms that ecological responses to Paleogene hothouse climates included the unicellular algal groups that constituted the base of food chains in ancient lake ecosystems.

* Corresponding author.

Copyright (c) 2009, SEPM (Society for Sedimentary Geology)

\section{MATERIALS AND METHODS}

The Giraffe Pipe locality $\left(64^{\circ} 44^{\prime} \mathrm{N}, 109^{\circ} 45^{\prime} \mathrm{W}\right)$ is a kimberlite diatreme that has been infilled by a sequence of middle Eocene lacustrine and paludal sediments and subsequently covered by Neogene glacial deposits (Figs. 1A-B). The Giraffe Pipe is one of many kimberlites in the Lac de Gras field in the Northwest Territories of Canada, most of which have Cretaceous or Paleogene emplacement ages (Heaman et al., 2004). A 165 $\mathrm{m}$ drill core collared at $47^{\circ}$ was obtained by BHP Billiton Diamonds Inc. in 1999 (core BHP 99-01) in order to assess the diamond potential of kimberlite underlying the maar sediments. This core contains $113.1 \mathrm{~m}$ of stratified organic sediment of middle Eocene age, including $44.8 \mathrm{~m}$ of peaty material underlain by $68.3 \mathrm{~m}$ of stratified lacustrine sediment, in many places finely laminated. Conversion of these core depths to their vertical equivalent implies stratigraphic thicknesses of $32.7 \mathrm{~m}$ for the peat and $51.1 \mathrm{~m}$ for lake sediments (Fig. 1C). Two air-fall tephra beds occur at the transition between lacustrine and paludal sedimentation, which marks the final infilling of the maar and incipient terrestrialization.

The age of this material is assessed in several ways. First, a ${ }^{87} \mathrm{Rb} /{ }^{87} \mathrm{Sr}$ model age from kimberlitic phlogopite is $47.8 \pm 1.4 \mathrm{Ma}$ (Creaser et al., 2004), providing a maximum age for lacustrine sedimentary sequence. Second, diameter-corrected $(\mathrm{n}=2)$ and isothermal-plateau $(\mathrm{n}=1)$ fission-track dates from the two tephra beds are highly coherent and statistically indistinguishable from $40 \mathrm{Ma}$ (J. Westgate, personal communication, 2007). Third, pollen assemblages from both lacustrine and paludal facies include what are believed to represent diagnostic middle Eocene elements, including Platycarya swasticoides and Pistillipollenites mcgregorii (Rouse, 1977; Hamblin et al., 2003). We therefore envisage that, following phreatomagmatic kimberlite emplacement, a lake formed rapidly within the crater and persisted for $\sim 7-8$ myr before terrestrialization. The maar crater was then colonized by a forest dominated by Metasequoia Miki (Cupressaceae), as indicated by abundant mummified wood, needles, and resinite droplets. It is important to note that the protracted regional tectonic and thermal stability of the Slave Craton, into which the Giraffe Pipe was intruded, has resulted in near-zero diagenetic alteration of the fossil content, as testified by preservation at the cellular level (Wolfe et al., 2006). For this reason, the site has already provided a number of insights concerning early history of nonmarine ochrophyte algae (Siver and Wolfe, 2005a; 2005b; 2007).

The current investigation is based on samples from $98.44-116.32 \mathrm{~m}$ in the core (71.99-85.07 m vertical equivalent depth). This interval corresponds to depths between $2.41 \mathrm{~m}$ and $14.49 \mathrm{~m}$ below the transition from lake to forest paleoenvironments, immediately beneath the two tephra horizons (Fig. 1C). In a paleolimnological sense, the lake was at this time shallow and dystrophic. Scaled chrysophytes were prolific (Siver and Wolfe, 2005a; 2005b), and diatoms suggest an acidic lake-water chemistry (Siver and Wolfe, 2007). Siliceous sponge spicules and disarticulated testate protozoan (rhizopod) scales are also abundant in this portion of the core, which is entirely consistent with this paleoenvironmental interpretation. In a general sense, synurophytes are more common 


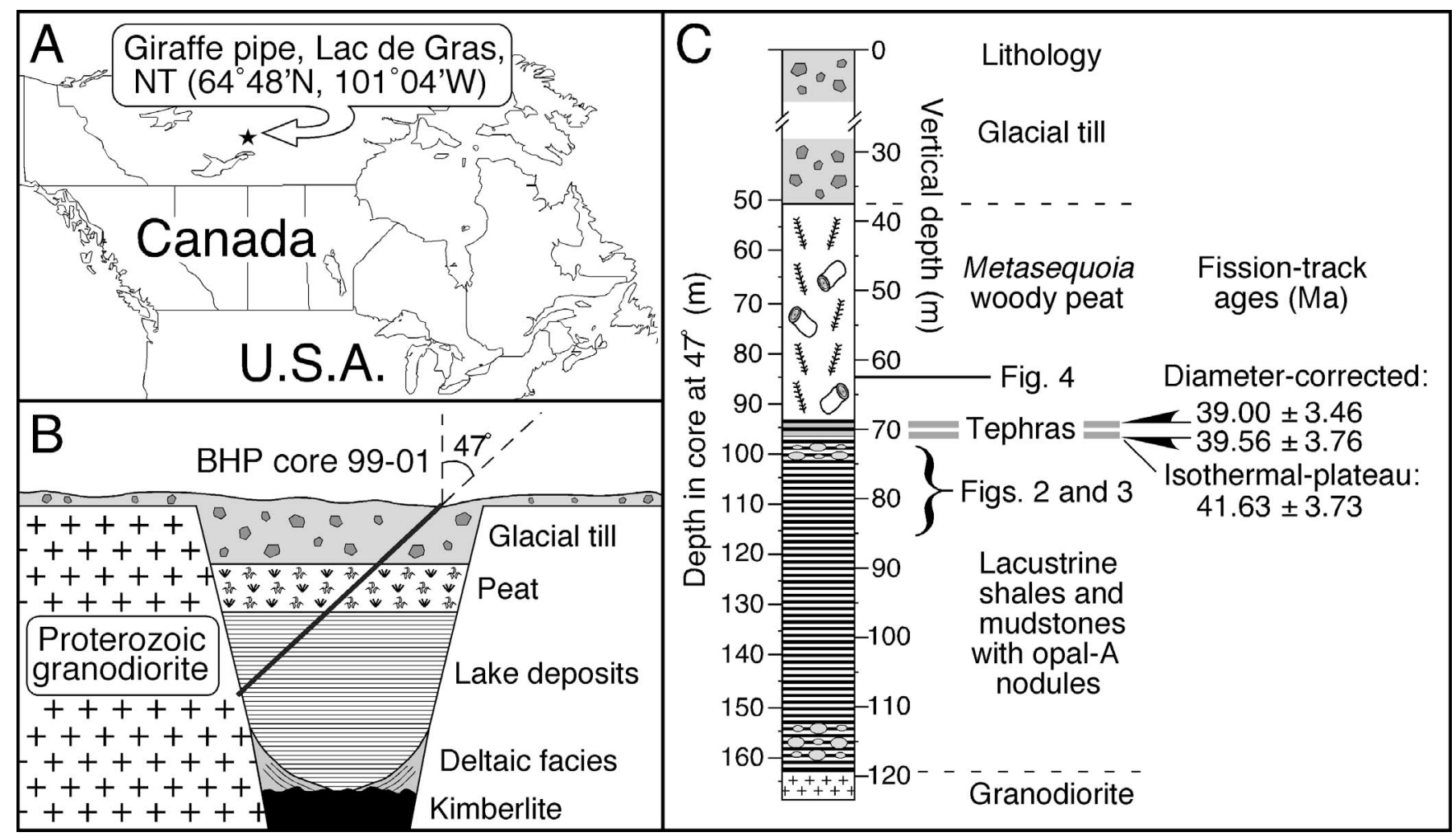

FIGURE 1-Location map and the Giraffe Pipe core. A) Location. B) Schematic stratigraphy. C) Lithostratigraphy and location of observations.

toward the top of this interval, whereas diatoms become more common lower in the section.

We conducted a detailed investigation using scanning electron microscopy (SEM) to fully explore the siliceous microflora of this interval. Small chips $(\sim 200 \mathrm{mg})$ of organic mudstone were first oxidized with $30 \% \mathrm{H}_{2} \mathrm{O}_{2}$ overnight and then centrifuged and rinsed several times. Aliquots of cleaned slurry were air dried onto heavy-duty aluminum foil, trimmed, and mounted to aluminum stubs with Apiezon wax. These stubs were coated with an Au-Pd mixture for two minutes in a Polaron Model E sputter coater prior to examination with a Leo 982 field emission scanning electron microscope.

We compared specimens of a Mallomonas taxon found in Giraffe Pipe sediments with modern forms of $M$. bangladeshica illustrated in the literature and with a population we examined from a subtropical locality in South America (Siver and Vigna, 1996). An archived sample from a site within the delta region of the Paraná River originally collected by Siver and Vigna in 1994 containing M. bangladeshica was dried onto aluminum foil and prepared for SEM as noted above. The length, width, and diameter of the grapnel structure (see below) were measured for twenty scales each from Giraffe Pipe sediments and the South American locality using SEM. The analysis of variance routine in SPSS (SPSS Institute Inc., 1999) was used to test for potential differences in the morphometric characters.

All Giraffe Pipe sediment samples and collections from the Paraná River delta examined as part of this work are archived in Siver's laboratory. Splits of all Giraffe Pipe samples are also stored in Wolfe's laboratory. Samples containing Actinella parva from Lake Judd, Tasmania, are maintained by W. Vyverman (University of Gent).

\section{OBSERVATIONS}

Mallomonas bangladeshica (Takahashi \& Hayakawa) Siver \& Wolfe nov. comb. (Figs. 2A-F)—Mallomonas bangladeshica was originally described from Bangladesh as Mallomonopsis peroneides (peronoides) var. bangladeshica by Takahashi \& Hayakawa (1979) and later transferred to the species level within the genus Mallomonopsis by Wujek and Timpano (1984). Asmund and Kristiansen (1986) merged the genus Mallomonopsis with Mallomonas, but these authors incorrectly listed Wujek and Timpano as the taxonomic authorities for Mallomonas bangladeshica. Recognizing that the transfer to the species rank within the genus Mallomonas had not been made, Nicholls (1988) proposed the combination, but this was done in error according to the rules of the International Code of Botanical Nomenclature because reference to the proper page(s) within the original publication of Takahashi and Hayakawa (1979) was not made. Kristiansen and Preisig (2007) make a valid transfer to Mallomonas at the variety level, but not for the species designation. The lack of a formal designation for this chrysophyte mandates the following combination:

Mallomonas bangladeshica (Takahashi \& Hayakawa) Siver \& Wolfe comb. nov.

Basionym: Mallomonopsis peronoides var. bangladeshica Takahashi \& Hayakawa (1979, p. 131, figs. 3-5 and 7-8).

Synonyms: Mallomonopsis bangladeshica (Takahashi \& Hayakawa) Wujek \& Timpano 1984; Mallomonas peronoides var. bangladeshica (Takahashi \& Hayakawa) Kristiansen \& Preisig 2007; Mallomonas bangladeshica (Takahashi \& Hayakawa) Nicholls 1988 (invalid combination).

Scales belonging to the synurophyte $M$. bangladeshica are readily identified by the presence of a unique appendage that rises perpendicularly to the base plate near the scale's apex (Figs. 2A-B, E-F). This appendage takes the form of a grappling hook or lobate umbrella (Figs. 2E-F). Although this feature is present on most, but not all, scales sheathing the cell, it is viewed as diagnostic of this chrysophyte (Siver and Vigna, 1996; Kristiansen, 2002). Some scales with reduced or rudimentary grappling hooks are also typically found on the posterior half of the cell (Figs. 2C-D). In Giraffe Pipe specimens, there are no evident morphological differences with extant forms. We observed scales with well-formed and spectacularly preserved grapnel hooks (e.g., Fig. 2A) that are virtually identical to modern scales of $M$. bangladeshica (cf. Fig. 2B), as well as scales with less-developed appendages (e.g., Fig. 2C) that are found on the cell covering today (cf. Fig. 2D). In addition, the range in length 

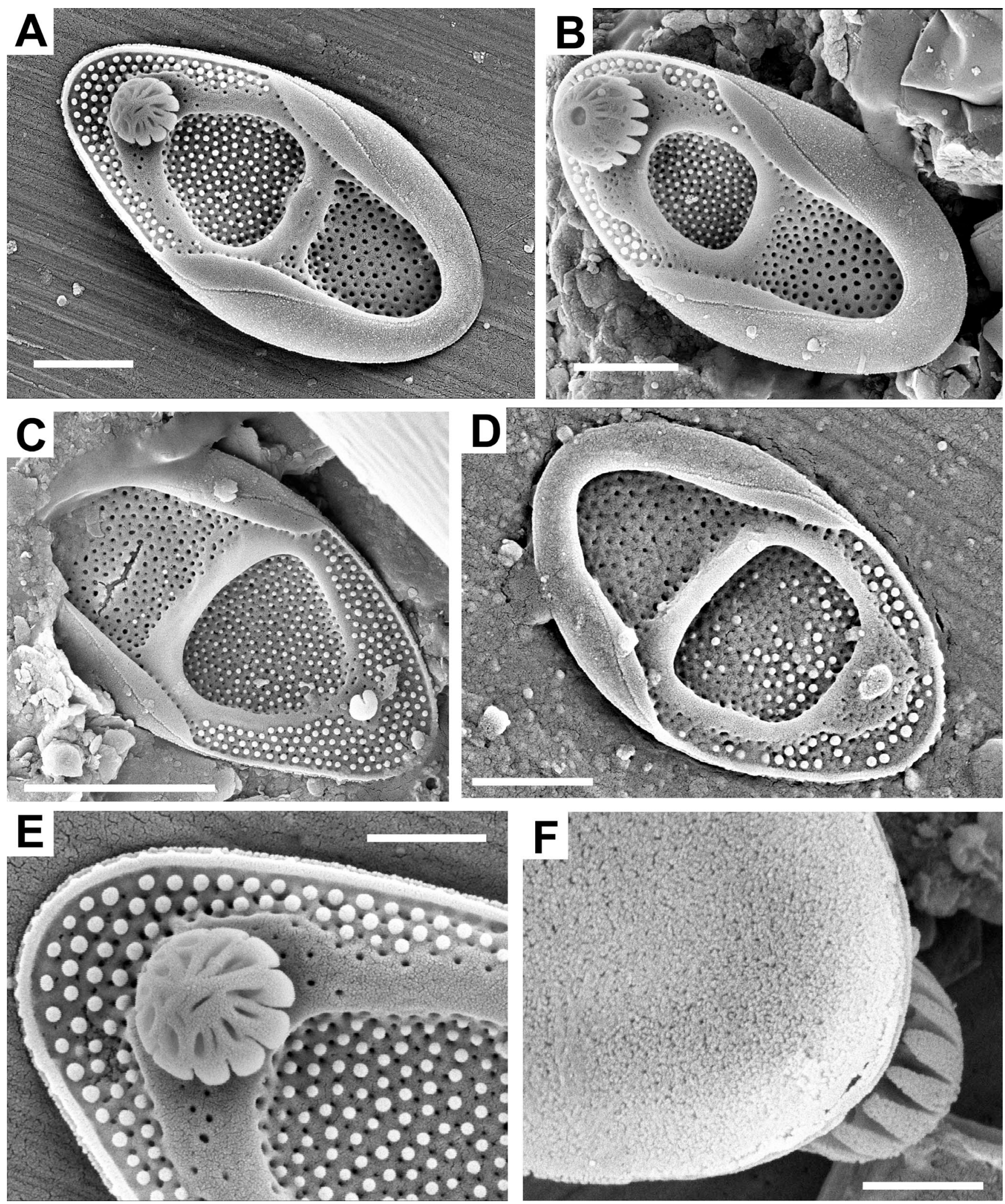

FIGURE 2-Fossil Mallomonas bangladeshica scales from Giraffe Pipe sediments (A, C, E-F) and modern forms from the Paraná River delta, Argentina (B, D). A-B Whole scales, each with a posterior upturned rim, anterior thickened margin, large anterior depression, surface papillae, and a well-developed grappling hooklike structure. C-D) Whole scales similar to those depicted in A-B, except with small rudimentary and reduced grappling hooklike structures. E) Close-up of the grappling-hook structure as viewed from the top. F) A scale with a fully formed, grappling hooklike structure as viewed from the undersurface of the scale. Scale bars $=500 \mathrm{~nm}$ in E-F; $1 \mu \mathrm{m}$ in $\mathrm{A}-\mathrm{B}, \mathrm{D}$; and $2 \mu \mathrm{m}$ in $\mathrm{C}$. 
(3.1-5.0 $\mu \mathrm{m})$ and width $(2.3-3.0 \mu \mathrm{m})$ of body scales and the diameter of the grapnel hook (650-850 nm) of Giraffe Pipe specimens were not significantly different from those observed for the living population of M. bangladeshica from South America examined as part of this study (length $=3.3-5.0 \mu \mathrm{m}$; width $=2.5-3 \mu \mathrm{m}$; diameter of grapnel hook $=600-900 \mathrm{~nm}$ ) and within the limits reported in the literature by Asmund and Kristiansen (1986). We conclude that, from morphological and size perspectives, the scales found in Giraffe Pipe sediments are similar to and, in most respects, indistinguishable from those of modern specimens of $M$. bangladeshica.

Mallomonas bangladeshica has hitherto been documented only from warm regions and has been classified accordingly as endemic to the tropics (Cronberg, 1989; Kristiansen, 2002). Taxonomically, M. bangladesh$i c a$ is placed within the series Peronoides (Asmund and Kristiansen, 1986), alongside M. stella Cronberg, $M$. ceylanica Dürrschmidt \& Cronberg, and M. peronoides (Harris) Momeu \& Péterfi. The former two taxa are also tropical, being reported from Africa and Asia, respectively, while the latter is more cosmopolitan but also restricted mostly to warm-region lakes (Siver and Vigna, 1996; Kristiansen, 2002). Our present observations (Figs. 2A, C, E-F) are the first fossil documentation of this chrysophyte lineage. The marked similarity between Giraffe Pipe and modern forms of $M$. bangladeshica mirror prior observations concerning additional chrysophyte genera from this deposit, collectively mandating prolonged evolutionary stasis within the synurophytes taken as a whole (Siver and Wolfe, 2005a; 2005b).

Actinella Lewis morphotype Giraffe 1 (Figs. 3A-D, G-H).-Abundant valves belonging to an undescribed diatom of the genus Actinella (hereafter: Actinella morphotype Giraffe 1) were found in the lower $2 \mathrm{~m}$ of the sediment section investigated here. Actinella is one of eight genera belonging to the Subclass Eunotiophycidae Mann in Round et al. (1990). Freshwater eunotioid diatoms are primarily distributed in acidic-todystrophic lake and wetland environments, where Eunotia is usually the most common genus (e.g., Patrick and Reimer, 1966; Krammer and Lange-Bertalot, 1991). The presence of Actinella in the Giraffe Pipe is thus ecologically consistent with our prior documentation of several morphotypes of Eunotia in the upper-lake facies of the core (Siver and Wolfe, 2007). Species of both Eunotia and Actinella possess a simple raphe positioned ventrally on each valve and terminating distally in distinct nodules near the apices (Round et al., 1990; Sabbe et al., 2001). Both genera have one or two simple rimoportulae per valve (Kociolek et al., 1997; Vyverman et al., 1998). Specimens from the Giraffe Pipe (Figs. $3 \mathrm{~A}-\mathrm{D}, \mathrm{G}-\mathrm{H})$, however, can be reliably assigned to Actinella because the valves are highly heteropolar in valve view, the frustules are clavate in girdle view, and the raphe slits are of unequal lengths. The raphe of Actinella morphotype Giraffe 1 differs from Eunotia in that it lies entirely on the margin of the valve face and not on the mantle.

Specimens of Actinella morphotype Giraffe 1 are small, range in size from 11-35 $\mu \mathrm{m} \times 1.8-2.8 \mu \mathrm{m}$, and have rounded head (Figs. 3G-H) and foot (Figs. 3C-D) poles. Although Actinella morphotype Giraffe 1 does not match exactly any modern species within the genus, it is most comparable to Actinella parva Vanhoutte \& Sabbe (Figs. 3E-F), a species known only from the highlands of Tasmania (Sabbe et al., 2001). Like Actinella morphotype Giraffe 1, valves of A. parva are small, range in size from 11-31 $\mu \mathrm{m} \times 1.5-2.3 \mu \mathrm{m}$ (measured at the midpoint), and have similarly rounded head and foot poles. In addition, frustules of both taxa are clavate in girdle view, possess one rimoportula per valve that can be on either pole (Figs. 3D, G-H), have similar striae densities, and lack marginal spines. The position of the raphe and the size of the helictoglossae differ slightly between the two species, but otherwise their morphologies are similar.

Most extant Actinella, including all species with less complex head poles like Actinella morphotype Giraffe 1, are distributed in tropical and subtropical regions of the world, largely in the Southern Hemisphere (Kociolek et al., 1997; Metzeltin and Lange-Bertalot, 1998; Sabbe et al., 2001), with remarkable diversity in the Amazon basin (Kociolek et al.,
2001; Metzeltin and Lange-Bertalot, 2007) and tropical Africa (Kociolek and Rhode, 1998; Sabbe et al., 2001). Synthesis of the 58 taxa in Actinella recognized and reviewed by Kociolek et al. (2001), Sabbe et al. (2001), and Metzeltin and Lange-Bertalot (2007) reveals that 34 are South American, 11 are African, and 9 are Australasian endemics, with relatively few cosmopolitan or temperate representatives (4 taxa). The type species, $A$. punctata Lewis, clearly fits within this last category. Actinella punctata was originally described from a small, acidic water body in New Hampshire in the United States (Lewis, 1864). Furthermore, unlike congeneric taxa with strongly regionalized distributions, it has been documented in temperate North America, northern Europe, the southern United States, Papua New Guinea, and tropical South America (e.g., Woodhead and Tweed, 1957; Kociolek et al., 1997; Camburn and Charles, 2000; Gaiser and Johansen, 2000; Sabbe et al., 2001; Metzeltin and Lange-Bertalot, 2007). Besides A. punctata, which has a more complex morphology than Actinella morphotype Giraffe 1, other reports of Actinella taxa from temperate localities are rare, and the genus as a whole has been characterized as tropical (Round et al., 1990).

By comparison, the fossil record of Actinella is far more cryptic, with only three documented localities outside the current investigation, none of which is presently tropical. Actinella penzhica was described from Oligocene-late Eocene deposits on the Kamchatka Peninsula (Lupikina and Dolmatova, 1982), whereas A. miocenica was described from Miocene sediments in the Jilin Province of northeastern China (Li, 1988). Actinella pliocenica was originally described from the Pliocene of France (Héribaud, 1902) and subsequently reported as extant in Sierra Leone (Woodhead and Tweed, 1957). When this admittedly sparse fossil record is augmented by the documentation of Actinella morphotype Giraffe 1 from the middle Eocene of northern Canada, it is possible to hypothesize that Actinella was once more widely distributed at northern high latitudes than at present.

\section{DISCUSSION AND CONCLUSIONS}

The documentation of Mallomonas bangladeshica and Actinella morphotype Giraffe 1 can be integrated with the goal of refining the understanding of Cenozoic ochrophyte biogeography. The first observation is that these algae are morphologically very similar to their closest extant relatives. Indeed, earlier claims for protracted evolutionary stasis among both the scaled chrysophytes (Siver and Wolfe, 2005a) and the diatoms (Wolfe et al., 2006; Siver and Wolfe 2007) appear strongly supported by the taxa described here. We furthermore argue that it is not only the morphology of the siliceous components of these organisms that has remained conservative but also their general ecological characteristics. The envisaged paleoenvironment of the Giraffe Pipe during the terminal lacustrine phase (Fig. 1C) is one of a productive, shallow, acidic, and perhaps dystrophic body of water facing encroachment by terrestrial vegetation, including Metasequoia forest. We believe this situation to have been limnologically similar to the habitats in which closely related taxa currently thrive, as reviewed above. That the latter habitats occur primarily in subtropical-to-tropical parts of the world has considerable implications for the interpretation of Giraffe Pipe ochrophyte assemblages.

The abundance of Metasequoia megafossils (wood and needle litter; see Fig. 4) in Giraffe Pipe sediments immediately overlying the limnic facies provides some measure of paleoclimatic inference concerning the site at the time of deposition. Reproductive growth of Metasequoia has been circumscribed to a mean annual temperature range of $9-17^{\circ} \mathrm{C}$, and mean annual precipitation regimes of 950-2040 mm (Mosbrugger et al., 2005; Liu et al., 2007). Given that the mean annual temperature and precipitation for Yellowknife, the closest meteorological station to the Giraffe Pipe locality, are $-5.4^{\circ} \mathrm{C}$ and $267 \mathrm{~mm}$, respectively, the middle Eocene climate of this region appears to have been at least $14^{\circ} \mathrm{C}$ warmer than present and approximately three times wetter. Under such conditions, the presence of ochrophyte algae with tropical ecological affinities appears less surprising, provided that adequate colonization vectors existed. 

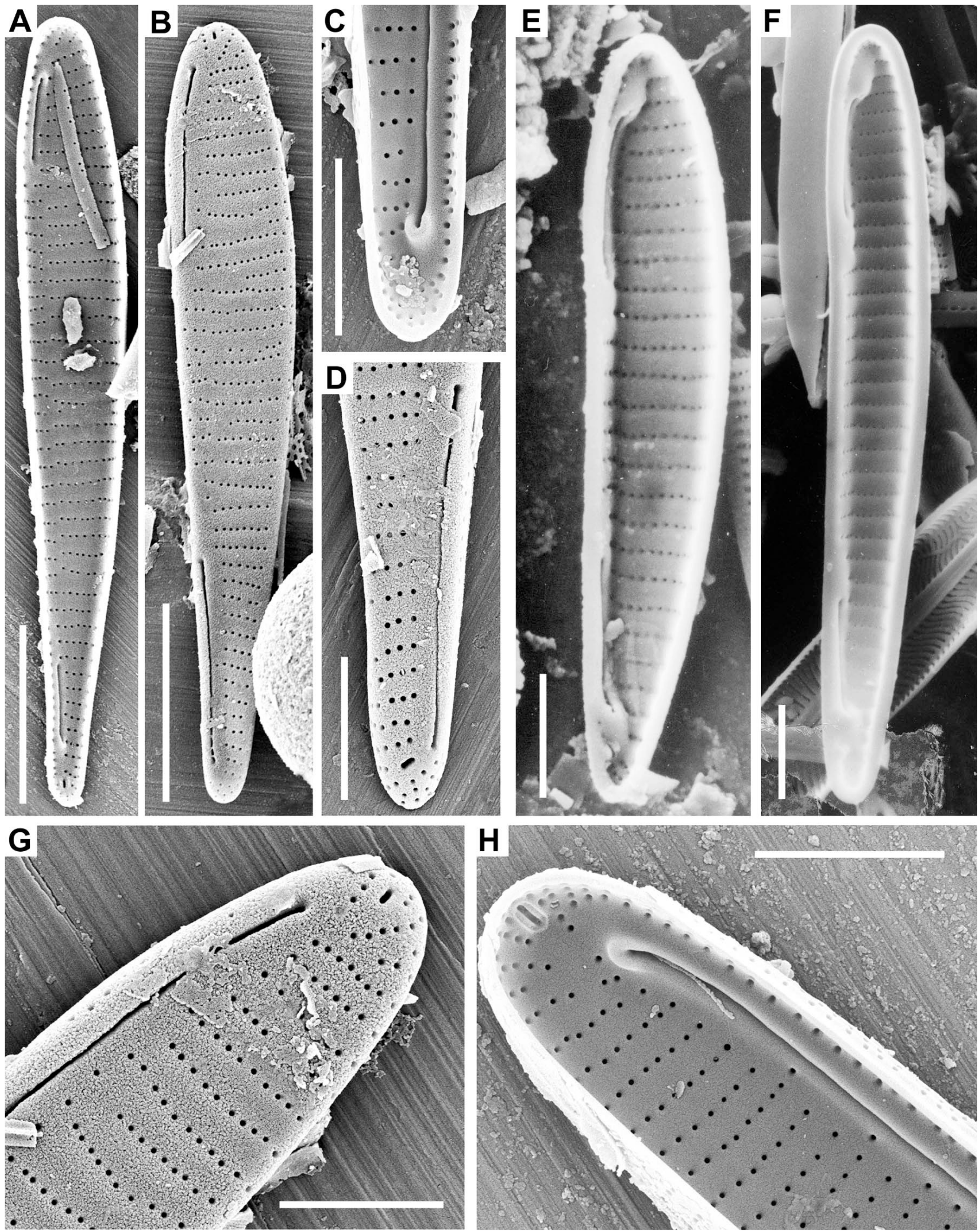

FIGURE 3-Valves of Actinella morphotype Giraffe 1 from Giraffe Pipe sediments (A-D, G-H) and the modern species, A. parva, from Lake Judd, Tasmania (E-F). AB) Internal (A) and external (B) views of whole valves. Note the varying lengths of the raphe slits and their position along the ventral surface on the valve face. C-D) Internal (C) and external (D) views of the foot pole. Note the position of the helictoglossa (C) and the presence of a rimoportula on the valve (D). E-F) Internal views depicting overall valve shape, raphe structure, and the helictoglossae. $\mathrm{G}-\mathrm{H})$ Internal $(\mathrm{G})$ and external $(\mathrm{H})$ views of the head pole depicting the position of the helictoglossa and rimoportula. Scale bars $=2 \mu \mathrm{m}$ in $\mathrm{C}-\mathrm{H} ; 5 \mu \mathrm{m}$ in $\mathrm{A}-\mathrm{B}$ ). 

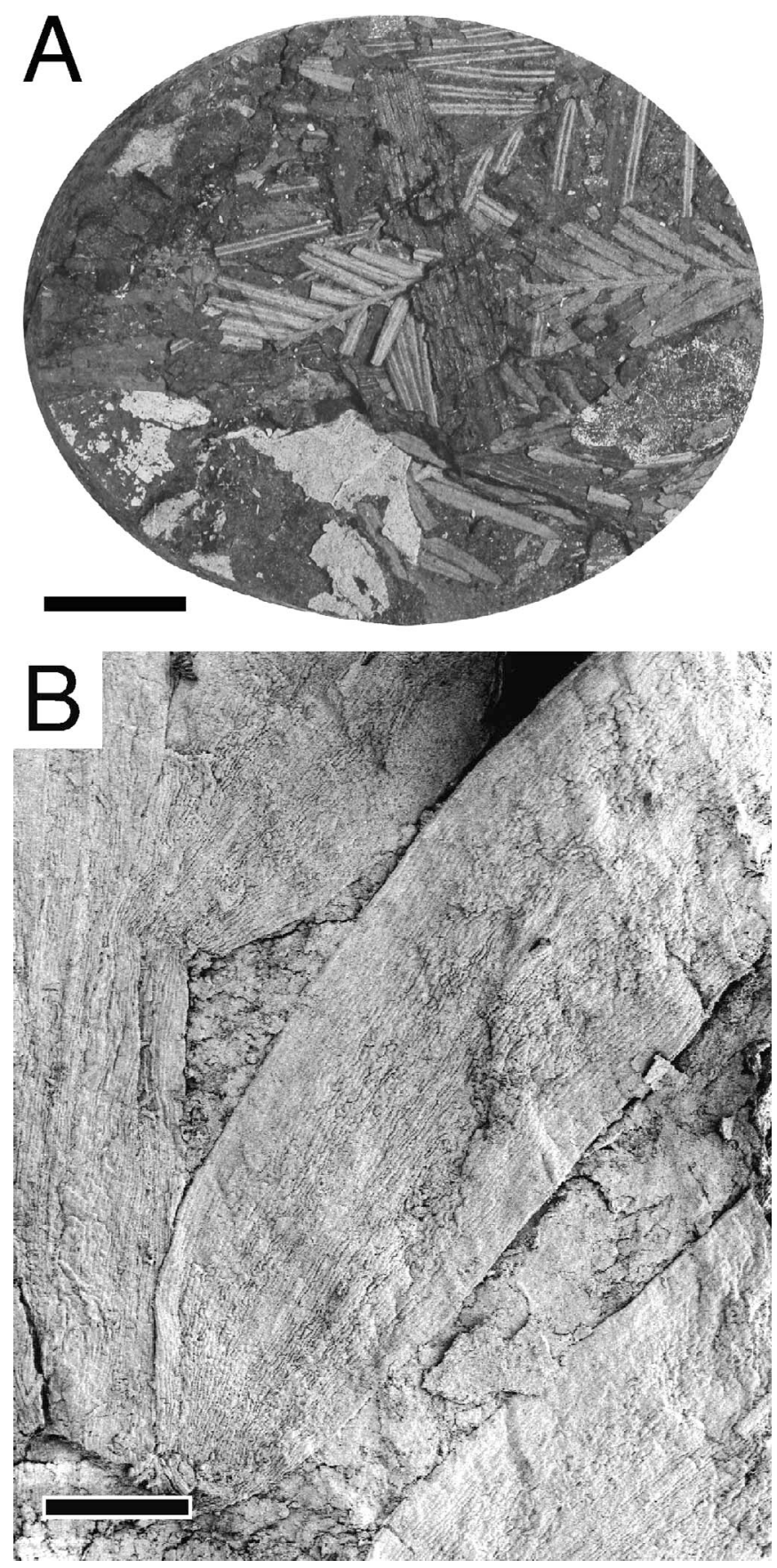

FIGURE 4-Examples of mummified Metasequoia glyptostroboides remains from Giraffe Pipe terrestrial sediments immediately overlying the lacustrine sequence. A) Litter dominated by $M$. glyptostroboides from a depth of $85 \mathrm{~m}$ in the core $(62 \mathrm{~m}$ equivalent vertical depth; cf. Fig. 1). B) Higher magnification scanning electron micrograph of Metasequoia needles reveal their exceptional preservation. Scale bars $=1 \mathrm{~cm}$ in $\mathrm{A}, 500 \mu \mathrm{m}$ in $\mathrm{B}$.

In this sense, warmer summers and greatly extended ice-free seasons may have facilitated the colonization and survival of warm-water organisms in freshwaters throughout the Arctic, heightened by the presence of a more active hydrological cycle. Subsequently, as Cenozoic climates began to cool, warm-adapted lake organisms either perished or followed the retraction of warm climate belts toward the equator. It therefore seems plausible that the few modern taxa we surveyed that can be found in temperate regions (e.g., Mallomonas peronoides, Actinella punctata) are in fact relictual taxa from warmer climate intervals, having adapted to survival in colder climates. This may explain why there exist, within both
Mallomonas series Peronoides and Actinella, a handful of scattered distributional records from the temperate zone despite an overarching biogeographic affinity with warm climate zones.

These observations have several fundamental implications. First, ochrophyte algae are demonstrably responsive to climate. Eocene greenhouse climates allowed the survival of ochrophytes with warm-water affinities in northern Canada, far north of any known occurrence of related extant taxa. Second, as global climates continue to warm under increased anthropogenic greenhouse-gas forcing, we may predict that warm-water ochrophytes will undergo important range expansions. Indeed, there is already strong evidence that such processes have been initiated, given that chrysophytes and diatoms with boreal affinities are beginning to appear in the Arctic (Wolfe and Perren, 2001; Smol et al., 2005). We predict this trend to continue apace with current and future warming of the planet (Hansen et al., 2006). Third, because ochrophytes play important roles at the base of aquatic food chains, such ecological reorganizations are likely harbingers of more profound ecological changes at higher trophic levels.

\section{ACKNOWLEDGMENTS}

This research was supported by the National Science Foundation, Division of Environmental Biology grant NSF-DEB-0716606 (United States) and the Natural Sciences and Engineering Research Council (Canada). We thank BHP Billiton Diamonds Inc. (Kelowna, British Columbia, Canada) and the Geological Survey of Canada (Calgary, Alberta) for providing access to the Giraffe Pipe material. John Westgate kindly provided key fission-track dates from the Giraffe tephra horizons, and Anne Lizarralde (Connecticut College) aided with sample preparation. We also thank Koen Sabbe and Wim Vyverman, who kindly supplied us with images of the modern taxon, Actinella parva, and Paul Silva for discussions on the rules of the International Code of Botanical Nomenclature regarding the taxonomy of Mallomonas bangladeshica.

\section{REFERENCES}

Asmund, B., and Kristiansen, J., 1986, The genus Mallomonas (Chrysophyceae): A taxonomic survey based on the ultrastructure of silica scales and bristles: Opera Botanica, v. 85, p. 1-128

Bice, K.L., Arthur, M.A., and Marincovich, L., JR., 1996, Late Paleocene Arctic Ocean shallow marine temperatures from mollusk stable isotopes: Paleoceanography, v. 11, p. 241-249.

Brinkhuis, H., Schouten, S., Collinson, M.E., Sluiss, A., Sinninghe Damsté, J.S., Dickens, G.R., Huber, M., Cronin, T.M., Onodera, J., Takahashi, K., Bujak, J.P., Stein, R., van der Burgh, J., Eldrett, J.S., Harding, I.C., Lotter, A.F., Sangiorgi, F., van Konijnenburg-Van Cittert, H., de Leeuw, J.W., Matthiessen, J., Backman, J., Moran, K., And the Expedition 302 Scientists, 2006, Episodic fresh surface waters in the Eocene Arctic Ocean: Nature, v. 441, p. 606-609.

Camburn, K.E., and Charles, D.F., 2000, Diatoms of low-alkalinity lakes in the northeastern United States: Academy of Natural Sciences of Philadelphia, Special Publication no. 18, 152 p.

Clyde, W.C., and Gingerich, P.D., 1988, Mammalian community response to the latest Paleocene thermal maximum: An isotaphonomic study in the northern Bighorn Basin, Wyoming: Geology, v. 26, p. 1011-1014.

Creaser, R., Grütter, H., Carlson, J., and Crawford, B., 2004, Macrocrystal phlogopite $\mathrm{Rb}-\mathrm{Sr}$ dates for the Ekati property kimberlites, Slave Province, Canada: Evidence for multiple intrusive episodes in the Paleocene and Eocene: Lithos, v. 76, p. 399-414.

CRonberg, G., 1989, Scaled chrysophytes from the tropics: Nova Hedwigia Beihefte, v. 95 , p. 191-232.

Gaiser, E.E., and Johansen, J., 2000, Freshwater diatoms from Carolina bays and other isolated wetlands on the Atlantic Coastal Plain of South Carolina, U.S.A., with descriptions of seven taxa new to science: Diatom Research, v. 15, p. 75130

Greenwood, D.R., and Basinger, J.F., 1994, The paleoecology of high latitude Eocene swamp forests from Axel Heiberg Island, Canadian High Arctic: Review of Paleobotany and Palynology, v. 81, p. 83-97.

Greenwood, D.R., and Wing, S.L., 1995, Eocene continental climates and latitudinal temperature gradients: Geology, v. 23, p. 1044-1048.

Hamblin, A.P., Stasiuk, L.D., Sweet, A.R., Lockhart, G.D., Dyck, D.R., Jagger, K. and SNowdon, L.R., 2003, Post-kimberlite Eocene strata within a crater basin, Lac 
de Gras, Northwest Territories, Canada [CD]: Eighth International Kimberlite Conference, Victoria, Canada, extended abstract, 5 pp.

Hansen, J., Sato, M., Reto, R., Lo, K., Lea, D.W., and Medina-Elizade, M., 2006, Global temperature change: Proceedings of the National Academy of Sciences, U.S.A., v. 103, p. 14,288-14,293.

Heaman, L.M., KJaRsgaARD, B.A., and Creaser, R.A., 2004, The temporal evolution of North American kimberlites: Lithos, v. 76, p. 377-397.

Héribaud, F.J., 1902, Les Diatomeés d’Auvergne: Premier Mémoire: Librairie des Sciences Naturelles, Paris, 79 p., 9 plates.

KalgutKar, R.M., and McIntyre, D.J., 1991, Helicosporous fungi and early Eocene pollen, Eureka Sound Group, Axel Heiberg Island, Northwest Territories: Canadian Journal of Earth Sciences., v. 28, p. 364-371.

Kelly, D.C., Bralower, T.J., and Zachos, J.C., 1988, Evolutionary consequences of the latest Paleocene thermal maximum for tropical planktonic foraminifera: $\mathrm{Pa}-$ laeogeography, Palaeoclimatology, Palaeoecology, v. 141, p. 139-161.

Kociolek, J.P., Lyon, D., and Spaulding, S., 2001, Revision of the South American species of Actinella, in Jahn, R., Kociolek, J.P., Witkowski, A., and Compère, P., eds., Lange-Bertalot-Festschrift: Gantner Verlag, Ruggell, Liechtenstein, p. 131165 .

Kociolek, J.P., and RHode, K., 1998, Raphe vestiges in "Asterionella" species from Madagascar: Evidence for a polyphyletic origin of the araphid diatoms?: Cryptogamie Algologie, v. 19, p. 57-74.

Kociolek, J.P., RHode, K., and Williams, D.M., 1997, Taxonomy, ultrastructure and biogeography of the Actinella punctata species complex (Bacillariophyta: Eunotiaceae): Nova Hedwigia, v. 65, p. 177-193.

Krammer, K., and Lange-Bertalot, H., 1991, Bacillariophyceae, pt. 3, Centrales, Fragilariaceae, Eunotiaceae, in Pascher, A., ed., Süßwasserflora von Mitteleuropa: vol. 2/3, Gustav Fischer Verlag, Stuttgart, Germany, 576 p.

Kristiansen, J., 2002, The genus Mallomonas (Synurophyceae): A taxonomic survey based on the ultrastructure of silica scales and bristles: Opera Botanica, v. 139, p. $1-218$.

Kristiansen, J., and Preisig, H.R., 2007, Chrysophyte and Haptophyte Algae, pt. 2: Synurophyceae, in Pascher, A., ed., Süßwasserflora von Mitteleuropa, vol. 1/2 Spektrum Akademischer Verlag, Germany, $252 \mathrm{p}$.

LEWIS, F.W., 1864, On some new and singular intermediate forms of Diatomaceae: Proceedings of the Academy of Natural Sciences of Philadelphia, v. 15, p. 336346.

LI, J.Y., 1988, A new fossil species (diatom) recorded and its significance: Bulletin of Botanical Research, Harbin, China, v. 8, p. 129-132.

LiU, Y.-J., Arens, N.C., and Li, C.-S, 2007, Range change in Metasequoia: Relationship to palaeoclimate: Botanical Journal of the Linnean Society, v. 154, p. 115127.

Lupikina, E.G., and Dolmatova, L.M., 1982, On new Paleogene species of the family Eunotiaceae (Bacillariophyta) from Kamchatka: Botanicheskii Zhurnal, v. 69, p. 1406-1408.

Metzeltin, D., and Lange-Bertalot, H., 1998, Tropical diatoms of South America: I. About 700 predominantly rarely known or new taxa representative of the neotropical flora: Iconographia Diatomologica, v. 5, p. 1-695.

Metzeltin, D., and Lange-Bertalot, H., 2007, Tropical diatoms of South America. II. Special remarks on biogeographic disjunction: Iconographia Diatomologica, v. 18 , p. $1-877$

Mosbrugger, V., Utescher, T., and Dilcher, D.L., 2005, Cenozoic continental climatic evolution of Central Europe: Proceedings of National Academy of Sciences, U.S.A., v. 102, p. 14,964-14,969.

Nicholls, K.H., 1988, Additions to the Mallomonas (Chrysophyceae) flora of Ontario, Canada, and a check-list of North American Mallomonas species: Canadian Journal of Botany, v. 66, p. 349-360.

Pagani, M., Zachos, J.C., Freeman, K.H., Tipple, B., and Bohaty, S., 2005, Marked decline in atmospheric carbon dioxide concentrations during the Paleogene: Science, v. 309, p. 600-603
PAK, D.K., and Miller, K.G., 1992, Paleocene to Eocene benthic foraminiferal isotopes and assemblages: Implications for deep water circulation: Paleoceanography, v. 7 , p. $405-422$.

Patrick, R., and Reimer, C.W., 1966, The diatoms of the United States: Monographs of the Academy of Natural Sciences of Philadelphia (Volume 1, Fragilariaceae, Eunotiaceae, Achnanthaceae, Naviculaceae): Academy of Natural Sciences of Philadelphia, $688 \mathrm{p}$.

Round, F.E., Crawford, R.M., and Mann, D.G., 1990, The Diatoms: Biology and Morphology of the Genera: Cambridge University Press, Cambridge, UK, 747 p.

RousE, G.E., 1977, Paleogene palynomorph ranges in western and northern Canada: American Association of Stratigraphic Palynologists Foundation, Contributions Series, ser. A, v. 5, p. 48-65.

Sabbe, K., Vanhoutte, V., Lowe, R.L., Bergey, E.A., Biggs, B.J.F., Francoeur, S. Hodgson, D., and Vyverman, W., 2001, Six new Actinella (Bacillariophyta) species from Papua New Guinea, Australia and New Zealand: Further evidence for widespread diatom endemism in the Australasian region: European Journal of Phycology, v. 36, p. 321-340.

Siver, P.A., and Vigna, S.M., 1996, Notes on species of Mallomonas in the series Peronoides (Mallomonadaceae, Synurophyceae): Nordic Journal of Botany, v. 16, p. 223-231.

Siver, P.A., and Wolfe, A.P., 2005a, Eocene scaled chrysophytes with pronounced modern affinities: International Journal of Plant Science, v. 166, p. 533-536.

Siver, P.A., and Wolfe, A.P., 2005b, Scaled Chrysophytes in Middle Eocene lake sediments from Northwestern Canada, including descriptions of six new species: Nova Hedwigia Beiheft, v. 128, p. 295-308.

Siver, P.A., and Wolfe, A.P., 2007, Eunotia spp. (Bacillariophyceae) from Middle Eocene lake sediments and comments on the origin of the diatom raphe: Canadian Journal of Botany, v. 85, p. 83-90.

Smol, J.P., Wolfe, A.P., Birks, H.J.B., Douglas, M.S.V., Jones, V.J, Korhola, A., Pienitz, R., Rühland, K., Sorvari, S., Antoniades, D., Brooks, S.J., Fallu, M-A., Hughes, M., Keatley, B.E., Laing, T.E., Michelutti, N., Nazarova, L., Nyman, M., Paterson, A.M., Perren, B., Quinlan, R., Rautio, M., Saulnier-Talbot, É., Siitonen, S., Solovieva, N., and Weckström, J, 2005, Climate-driven regime shifts in the biological communities of arctic lakes: Proceedings of the National Academy of Sciences, U.S.A., v. 102, p. 4397-4402.

SPSS Institute Inc., 1999, Introductory Statistics Guide to SPSS: Chicago, Illinois, $276 \mathrm{p}$.

Takahashi, E., and Hayakawa, T., 1979, The Synuraceae (Chrysophyceae) from Bangladesh: Phykos, v. 18, p. 129-147.

Vyverman, W., Sabbe, K., Mann, D.G., Kilroy, C., Vyverman, R., Vanhoutte, K. and Hodgson, D., 1998, Eunophora gen. Nov. (Bacillariophyta) from Tasmania and New Zealand: Description and comparison with Eunotia and amphoroid diatoms: European Journal of Phycology, v. 33, p. 95-111.

Wing, S.L, AlroY, J., and Hickey, L.J., 1995, Plant and mammal diversity in the Paleocene to early Eocene of the Bighorn Basin: Palaeogeography, Palaeoclimatology, Palaeoecology, v. 115, p. 117-155.

Wing, S.L., Harrington, G.J., Smith, F., Bloch, J.I., and Boyer, D.M., 2005, Transient floral change and rapid global warming at the Paleocene-Eocene boundary: Science, v. 310, p. 993-996.

Wolfe, A.P., Edlund, M.B., Sweet, A.R., and Creighton, S., 2006, A first account of organelle preservation in Eocene nonmarine diatoms: Observations and paleobiological implications: PALAIOS, v. 21, p. 298-304.

Wolfe, A.P., and Perren, B.B., 2001, Chrysophyte microfossils record marked responses to recent environmental changes in high- and mid-arctic lakes: Canadian Journal of Botany, v. 79, p. 747-752.

WoodHeAd, N., and TweEd, R.D., 1957, Revision of the diatom genus Actinella Lewis (Tibiella Bessey): Biologisch Jaarboek, v. 24, p. 204-233.

Wujek, D.E., and Timpano, P., 1984, The genus Mallomonopsis in the United States: Transactions of the Kansas Academy of Science, v. 87, p. 73-82.

Zachos, J.C., Dickens, G.R., and Zeebe, R.E., 2008, An early Cenozoic perspective on greenhouse warming and carbon-cycle dynamics: Nature, v. 451, p. 279-283.

ACCEPTED SEPTEMBER 16, 2008 